\title{
Language and Gender Representation in Chinua Achebe's Things Fall
}

\section{Apart}

\author{
Blessing U. Ijem ${ }^{1} \&$ Isaiah I. Agbo ${ }^{2}$ \\ ${ }^{1}$ Department of English and Literary Sudies, Federal University, Wukari, Nigera \\ ${ }^{2}$ Department of English and Literary Sudies, University of Nigeria, Nsukka, Nigera \\ Correspondence: Isaiah I. Agbo, Department of English and Literary Sudies, University of Nigeria, Nigera.
}

\author{
Received: September 10, 2019 Accepted: October 23, 2019 Online Published: October 25, 2019 \\ doi: $10.5539 /$ elt.v12n11p55 \\ URL: https://doi.org/10.5539/elt.v12n11p55
}

\begin{abstract}
This article examines the linguistic construction of gender in Chinua Achebe's Things Fall Apart. It shows how this reflects the social reality of the relationships between women and men in society, which is firstly structured in the unconscious mind. The examination of language use in constructing genders in the novel is important as it unveils the relationships between the male and the female in society. This is because gender representation is influenced by unconscious and hidden desires in man. This study specifically examines Achebe's use of grammatical categories in the construction of the male and female genders in Things Fall Apart. To this end, it reflects the pre-colonial Igbo society in its socially stratified mode, which language served as the instrument for both exclusion and oppression of women. This article shows that the male and female genders dance unequal dance in a socially, politically and economically stratified society where the generic male gender wields untold influence over women in that pre-colonial Igbo society. The study further shows that Achebe used language in Things Fall Apart to glorify masculine gender while portraying the female gender as docile, foolish, weak and irresponsible second-class citizen.
\end{abstract}

Keywords: language, gender representation, Chinua Achebe, Things Fall Apart

\section{Background}

In our socio-cultural settings, there exist some linguistic asymmetries which mark one gender off from the other and reveal the attitude of one gender toward another. Gerda Lerner cited in Butler maintains that, 'gender is the costume, a mask, a strait jacket in which men and women dance that unequal dance' (Butler, 1990). 'Unequal dance' as used by Gerda entails socio-cultural inequality scaffold by language. Gender is therefore, the outcome of human interactions, social life and the structure of a particular society. West and Zimmerman (1987) posit that gender is a human production just like culture and, it is dependent on everyone constantly 'doing gender'. In society, one gender is usually assumed to be superior to the other leading to structured inequality where the subordinate gender has less power, prestige and economic rewards than the valued and dominant gender.

The female gender is usually 'depersonalized and socially constructed as secondary and subservient to the generic male gender' (Moreblessings, 2006). The female gender is often presented in literature as the sexually domesticated being; a weak vessel whose duties are to produce children and prepare food for the family. A man who fails to fulfil his roles in society is usually referred to as a woman, which demonstrates the underlying attitudes towards women. In Achebe's Things Fall Apart it is stated, 'No matter how prosperous a man was, if he was unable to rule his women and children (and especially his women) he was not really a man' (Achebe, 1991). Through this kind of linguistic gender construction, the idea of masculinity is obvious in all aspects of the pre-colonial Igbo society.

\section{Literature Review}

Guthrie in a study entitled Language and Identity in Postcolonial African Literature: A Case Study of Chinua Achebe's Things Fall Apart, for language attitudes, reveals that, an author's linguistic stereotypes can affect his writing and promote cultural bias (Guthrie, 2011). Nikolas Coupland and Adam Jaworski have noted that 'our beliefs may be the factor motivating our behaviours, whatever the objective truth is (267). The combined literary and linguistic approach challenges readers to think about culture, language, identity, and the importance of language attitudes on the writing process. This is vital inasmuch as language reflects cultural beliefs and reveals 
what goes on in the mind. The choices regarding vocabulary and grammar in a literary text are both consciously and unconsciously 'principled and systematic', (Fowler et al., 188), thus requiring a critical examination of the thought processes and patterns.

Commenting on the construction of male and female genders in the autobiographical narratives, Ogunyemi et al maintain that gender differences are created and sustained by society through its traditional machinery, such as its conventions, norms, institutions and laws (99). The idea about male and female as it has to do with gender include traditional views that mark 'women as submissive, illogical, passive, talkative, emotional, easily given to tears, etc. Men on the other hand are assumed to be competent, logical and independent..." (Behringer, 2008). A social constructionist view of gender looks beyond categories and examines the intersections of multiple identities and the blurring of the boundaries between essentialist categories. This is especially true with regard to categories of male and female, which are viewed typically as binary and opposite.

One of the primary means in the expression of gender is speech. This is in tandem with Duranti's belief that language can do things beyond the performative functions of verbs such as promise, pronounce and apologize (458). He states that some linguistic features can index, or point to a connection between a person and a place or a profession. In addition, he points out that the pronoun (he, she) which indexes a person's gender can affect the way the person is perceived. Parker and Sedgwick argue that performativity makes it possible for an in-depth appreciation of the ways identities are constructed in texts (2), just as Renzetti and Curran has maintained that the moment parents are asked to describe their 24 hours old infants, parents do so using gender-stereotypic language: boys are described as strong, alert and coordinated while girls are described as tiny, soft and delicate (Renzetti \& Curran, 1992). It has also been observed that there are a lot of linguistic resources and embodied performances that express gendered meaning such as pitch, intensity, and loudness (Smyth et al., 2003). Sapir also holds that 'language is the medium of literature just as marble, bronze or clay are materials of sculpture' (222). In literature, language is employed in the construction of gender types and roles of each gender type is described using language and linguistic resources that mirror unbalances view of the male and female genders.

Other researchers such as Baxter (2003), Kiesling (1997, 2003), Pujolar (2000) and some discursive psychologists such as Edley and Wetherell (1997) and Speer (2002) have focused 'on the diversity of gendered linguistic performance produced in different local contexts by single individuals or small groups' (Cameroon, 2005). They studied the way their subjects, instead of occupying a consistent gendered position, seem to orient to and/or be positioned by others through a continually shifting range of discourses on masculinity and femininity. It has been noted that men represent themselves in text and talk as responsible and professionally successful people but in some contexts, discussion of women is crudely objectifying, sexist and implicitly homophobic. This shows that some range of gendered performances can be found in the repertoire of every group, and indeed every individual subject in society.

Although gender is interpreted as a social construct, it has the capacity to influence the experiences of the people. It could be argued then that gender structures interaction opportunities, consciousness, ideology and the forms of resistance that characterize the life of a people. Gender refers to roles, attributes and values assigned by culture and society to women and men. It is "the socially constructed roles of and relations between males and females" (Zola, 2010). Gender is often marked by unequal power relations that assign definite entitlements and responsibilities to men only. This leads to the emergence of gender sensitivity, a situation whereby people become aware of what others think about gender to challenge the orthodox views and assumptions of the roles of men and women in society. Gender sensitivity neutralizes the patriarchal status quo where 'men have social power in every important structure of society and ... women do not have any real access to such structures' (Zola, 2010). Gender sensitivity pays a great deal of attention to the various similarities and differences between men and women with respect to their experiences and viewpoints. Gender sensitivity is committed to giving equal value and opportunity to both men and women in society. In other words, it has to do with the awareness and the appreciation of the need to maintain at a reasonable level, the gender difference between the man and female.

In Nigeria, for instance, there is gender profiling which points at gender imbalance, gender inequality, gender bias and gender discrimination and they manifest in literature. The interpretation of the above assertion is that males are favoured and treated preferentially to the detriment of their female counterparts in literary works such as Chinua Achebe's Things Fall Apart which is a reflection of the goings on in society. In the third world countries, men dominate virtually every aspect of governance and use their position and status to accumulate power and wealth. In Igbo culture for example, decision making has remained the prerogative of the masculine gender that is fondly called "Onyeisiala". Ahituhu and Ajakor decry female subjugation by male. They assert that... women are excluded from some central activities crucial to humanity such as the defining activities of modern political identity, which men appeared to be granted by natural flat. These included the right to take an 
active role in politics, government and leadership. The right to political representation, the right to education, the right to self-definition, the right to legal ownership and the right to bequeath an inheritance (769).

Since gender has transcended the biological make up of persons, to include what one does, this paper explores the various ways in which society linguistically constructs gender characteristics in Achebe's Things Fall Apart.

\section{Theoretical Framework}

This study adopts an eclectic approach and draws from Fairclough's model of Critical Discourse Analysis (CDA), Halliday's Systemic Functional Linguistics (SFL) and Psychoanalytic Theory. Critical discourse analysis examines the relationship between power relations, dominance, inequality and bias in a text (Fairclough, 1995). In analyzing a text or communicative event, there are three areas that CDA focuses. They are text (e.g. a novel), discourse practice (e.g. the process of production and consumption), and sociocultural practice (e.g. social and cultural structures which give rise to the communicative event) (Fairclough, 1995; systemic functional linguistics accounts for the meaning of language structures in the novel; psychoanalysis helps in the examination of the cultural phenomena and how gender representation is influenced by unconscious and hidden desires in man.

\section{Data Presentation and Analysis of Gender Representation in the Text}

This section of the analysis examines specific examples to show the extent of imbalance Achebe betrays in his construction of the male and female characters. This dimension is captured succinctly in the excerpts below:

He had a large barn full of yams and he has three wives (P. 5).

Okonkwo is portrayed in excerpt one as a wealthy man. His wives and children depend wholly on him for their survival. He has a large barn full of yams' and married three wives. Okonkwo was not only wealthy, but could conveniently keep and control three women. In this portrayal, Okonkwo is the provider, sustainer, saviour and ruler of his wives. The ideology here is that irrespective of the number of women a man marries, he can rule over them because he has the capacity, wisdom and authority to do so. Okonkwo's wealth points to his industriousness which the masculine gender is known for in Achebe's Things Fall Apart, while his masculinity enables him to marry three wives and keep them under his control. Thus the male and female genders have been unevenly portrayed.

In excerpt 2 below, it is further shown that marrying many wives and having total control over them is a mark of wealth and an exclusive attribute possessed by men. Let us consider it.

He was a wealthy farmer and had two barns full of yams and had just married his third wife (P. 7).

Okonkwo is still the character being described in the excerpt above. It can be seen that men are constructed as industrious. They are painted as those who work very hard, acquire wealth and marry as many wives as possible. The ideology of men controlling all the resources aids patriarchal hegemony in society. Also, the logic underlying the role and attributes assigned to men reinforces the belief that men are naturally superior, intelligent and responsible. On the other hand, one may acknowledge that Achebe is not suggesting that all men are intelligent and responsible especially when one considers the difference between Okonkwo and his father Unoka who is considered a worthless man in society. His projection actually agrees with the traditional trend in a patriarchal society which Achebe creates.

We are introduced to a patriarchal society that privileges the male children over the female. The excerpt below captures the psychology of the society that is depicted in Achebe's Things Fall Apart.

Do you think you are cutting up yams for cooking? He asked Nwoye. If you split another yam of this size, 1 shall break your jaw. You think you are still a child. I began to own a farm at your age. And you, 'he said to Ikemefeuna, 'do you not grow yams where you come from?' Inwardly, Okonkwo knew that the boys were still too young to understand fully the difficult art of preparing seed-yams. But he thought that one could not begin two early. Yam stood for manliness, and he who could feed his family on yams from one harvest to another was a very great man indeed. Okonkwo wanted his son to be a great farmer and a great man (P. 26).

In the excerpt above, attention is drawn to the rigorous process adopted by Okonkwo to ensure that his son, Nwoye and Ikemefuna become men indeed, especially his son, Nwoye. 'Yam stood for manliness' and this is why Okonkwo is preoccupied with training his son to become a man by developing his manliness. Although Okonkwo knows inwardly that the boys are two young to prepare seed-yams, yet he wants them to begin early to learn the art, since it is a difficult one and he could not afford to have a failed son. The ideology and logic behind this rigorous training of the boys is to ensure that they do not appear feminine since yam stands for manliness.

Men are rated based on their ability to feed their families on yams from one season to another. Okonkwo declares that he began to own farms at the age of his son, Nwoye. This implies that he became a great man at a 
very young age. Any great farmer is a great man and because Okonkwo is a great man, he wants his son to be a great man too. This further demonstrates gender role specification. No mention was made to Okonkwo's daughters. This shows how the girl-child is neglected in the pre-colonial Igbo society. Yam planting is an exclusive reserve for the men and this is a mark of honour. 'Women planted maize, melons and beans between yam mounds'. This is a lesser work that does not require tact or energy but 'yam, the king of crops, required a lot of energy. The ideology here is that men are superior to women.

In the extract below, Okonkwo is projected as a wealthy, non-pleasure-seeking and hardworking man. The evidence of his wealth is demonstrated by the large crowd he invites to the yam festival and feeds them on yam because his 'arm was strong'. Societal belief is evident here and polarizes between men and women. Men's arms are strong, that is, they are wealthy and can take up the responsibility of feeding their wives' relations during the festival. Achebe gives a balanced projection of the situation when he says that a man 'whose arm was strong' invites large number of guests for the festival.

The New Yam Festival was thus an occasion for joy throughout Umuofia. And every man, whose arm was strong, as the Ibo people say, was expected to invite large numbers of guests from far and wide. Okonkwo always asked his wives' relations, and since he now had three wives his guests would make a fairly big crowd. But somehow Okonkwo could never become enthusiastic over feasts as most people.... he was always uncomfortable sitting around for days waiting for a feast or getting over it. He would be very much happier working on his farm. (P. $30)$.

Men are constructed as individuals who are not pleasure-seeking. While women and children are painted as being enthusiastic over feasting and are individuals who are busy with decorating the house and preparing the meal. As for Okonkwo, 'He could be happier working on his farm'. This shows that men are industrious while the women are lazy and pleasure-seeking. Thus, the writer creates the ideology which determines the role patterns and norms that make inequality appear natural and inevitable, especially in the Igbo society. Men are presented as heroes who bring wealth and comfort to their families.

In the excerpt below, Okonkwo is presented as a great wrestler in the novel. The sound of the drum ignited and rekindled the fire of victory in him. He begins to tremble with the desire to conquer and subdue. While the men wrestle, the women as passive creatures could only watch, clap and laugh. Wrestling is for the men and Okonkwo is a renowned wrestler. Wrestling requires a lot of energy and tact which only the men, as the stronger and superior beings possess.

The drums beat the unmistakeable wrestling dance-quick, light and gay, and it came floating on the wind. Okonkwo cleared his throat and moved his feet to the beat of drums. It filled him with fire as it had always done from his youth. He trembled with the desire to conquer and subdue (P. 34).

The excerpt below portrays men more superior to and as stronger than women. The ideology behind the careful crafting and construction of the male and a female in the text in a polarized manner is apparently intended to question the women's claim that 'whatever a man can do, women can do it better'. The boys and Obiageli were each given a pot fit for their ages. This is to show equality, fairness and justice between the female and male genders. However, Obiageli quickly fizzled out as she could not carry her own pot of water safely, and consequently, she broke it. None of the boys broke their pots. The boys are portrayed as not only being more intelligent than Obiageli, but also more careful. The meaning of the name Obiageli 'I have come to eat' further suggests that the female gender is only after pleasure and not work.

The weeping was now quite close and soon the children filed in, carrying on their heads various sizes of pot suitable to their years. Ikemefuna came first with the biggest pot, closely followed by Nwoye and his two younger brothers. Obiageli brought up the rear, her face streaming with tears. In her hand was the cloth pad on which the pot should have rested on her head. (P. 35).

Another thing to note here about linguistic gender construction is that while men are portrayed as very careful, the women are portrayed as both careless and carefree. While Obiageli does 'Inyanga' (shows off absurdity) with her pot, the boys carefully protected theirs from breaking. Women are also projected as wasters based on the fact that Obiageli broke her pot which cost a fortune while the boys are portrayed as mindful and protective. While the male gender is portrayed in a good light, the female gender is cast on a bad light.

So Okonkwo encouraged the boys to sit with him in his Obi, and he told them stories of the land masculine stories of violence and bloodshed (P. 42).

As can be seen in the excerpt above, every society has its own socializing engines. These socializing engines are captured in appropriate language use which a skilled writer presents in his works as in Things Fall Apart; hence 
Okonkwo had told the boys masculine stories of violence and bloodshed. Young men are taught to be tough and hard hearted by the kind of stories they are told. So there is a polarization between women and men in society resulting from the kind of education they receive. This kind of education or indoctrination aids the functions of the men and the women in a given society and encourages gendered roles. As defenders of their wives and children, men are prepared for war while women are prepared for home keeping and child rearing. This reveals the fact that patriarchal structures are transmitted through literature and expressed in language, thus setting male and female genders apart.

At the beginning of their journey, the men of Umuofia talked and laughed about the locusts, about their women, and about some effeminate men who had refused to come with them (P. 47).

Men are portrayed here as hard-hearted set of individuals who could not condone weakness in men for any reason. At the time set for Ikemefuna's execution, some men withdrew from the task and are tagged 'effeminate men'. Men who declined going with them were seen as not been strong hearted hence the use of the adjective 'effeminate' to qualify them. This implies that men are strong while women are weak. Men make jest of their women because to them, the women have no strong mind and could not do certain things. Women can only tell stories and revel in pleasure. The word 'effeminate' used for the description of the men who could not come with Okonkwo and the others is meant to humiliate them and classify them as women, full of fears. But real men are brave and daring and could stop at nothing in order to show their manliness, even when it involves killing Ikemefuna who had lived with Okonkwo for three years and called him father.

'When did you become a shivering old woman', Okonkwo asked himself, 'you who are known in all the nine villages for your valour in war?' how can a man who has killed five men in battle fall to pieces because he has added a boy to their number? Okonkwo you have become a woman indeed? He sprang to his feet, hung his goatskin bag on his shoulder and went to visit his friend, Obierika. (P. 51).

Bravery and valour are ascribed to men in the excerpt above. Okonkwo is ruminating on the experience of killing Ikemefuna. He appears to show weakness and fear but he promptly chides himself for expressing attributes which belong to women. He asks himself rhetorically, 'when did you become a shivering old woman?' This implies that weakness and fear are associated with women and not men. Men are courageous and carry out heroic deeds of which the killing of Ikemuefuna is just one. Okonkwo is famous for his valour in war throughout the nine villages of Umuofia where he has killed five men. When he recounted this to himself, he dismissed fear and remorse for killing a boy who calls him father. He sprang to his feet and sets out to visit his friend, Obierika. Okonkwo has told Nwoye tragic stories of war and bloodshed in order to inculcate in him the manly attributes of valour and fearlessness. So, fear has nothing to do with men. They are fearless, courageous and heroic in character.

It was always said that Ndule and Ozoemena had one mind', said Oberika..... 'I did not know that' said Okonkwo. 'I thought he was a strong man in his youth' (P. 54).

Any man who shares ideas with women before executing them is considered to be weak. The societal belief about men is that men are superior, independent and courageous. A man who subjects his opinion to his wife's consideration and possible approval is a weakling. Hence, Ndule is a weakling for sharing his ideas with his wife, Ozoemena. That Ndule shared ideas with his wife surprised Okonkwo, hence Okonkwo's declaration, 'I thought he was a strong man in his youth'. Men are described as absolute rulers who make and implement whatever decision they want while the women are to say 'Amen'.

In the extract below, Okonkwo is constructed as a demi-god in his home. His wives are not expected to go close to his door except upon invitation.

Okonkwo turned on his side and went back to sleep. He was roused in the morning by someone banging on his door. 'Who is that? He growled... of his three wives Ekwefi was the only one who would have the audacity to bang on his door. (P. 60).

Okonkwo is both dreaded and feared by his wives. He ruled his family with an iron hand and none of them but Ekwefi could have the audacity to bang on his door. The 'he growled' is used in the excerpt to show the fierceness with which Okonkwo speaks to his wives. He is a domineering head and a threat to his wives. Instead of honouring and respecting men, women dread and fear them. It is completely audacious for women to knock on their husbands' doors. They must be invited by their husband before they enter men's hut.

The asymmetrical portrayal of the emotional configuration of the two genders in Achebe's language is obvious from the extract below:

'Ezinma is dying', came her voice, and all the tragedy and sorrow of her life were packed in those words. 
Okonkwo sprang from his bed, pushed back the bolt of his door and ran into Ekwefi's hut.... 'It is Iba' said Okonkwo as he took his matchet and went into the bush to collect the leaves and grasses and barks of trees that went into making the medicine for $I b a$ (P. 60).

There are sharp contrasts between men and women as projected in the extract above. While Ekwefi is portrayed as being emotional and confused, Okonkwo is portrayed as a courageous man who could promptly arrest any situation. That women are emotional is encapsulated in the expression '... all the tragedy and sorrow of her life were packed in those words'. Men as represented by Okonkwo are portrayed as brave, agile and as solution providers. While Ekwefi is sorrowful and in a pensive mood, Okonkwo 'sprang from his bed', 'pushed' back the bolt of his door', discovers what is wrong with Ezinma and declared that 'it is Iba', and dashes into the bush to gather herbs, roots and barks of tree to produce the medicine to cure Ezinma's Iba. Men are thus portrayed positively as more decisive in the face of danger than women who are usually confused in the face of danger or adversity.

It was clear from the way the crowd stood or sat that the ceremony was for men. There were many women, but they looked on from the fringe like outsiders. The titled men and elders sat on their stools waiting for the trial to begin (P. 70).

The domineering and absolute rulership of men over women is further described in the above extract above. This expression in the extract disambiguates any contradiction to this claim: 'It was clear from the way the crowd stood or sat that the ceremony was for men'. Women have no voice in the pre-colonial Igbo society. They could not express themselves in issues that concern them. The elders and titled men have taken their place in court to decide the case between Ezewulu and Mgbafo, his wife. Women are to be seen and not heard. Achebe's society is a patriarchal society. Mgbafo herself who is directly involved in the matter has to be represented by his brothers since society has considered it unacceptable for a woman to talk before men.

'My in-law has told you that we went to his house, beat him up and took our sister and her children away, all that is true.... My sister lived with him for nine years. During those years no single day passed in the sky without him beating the woman.... 'Two years ago', continued Odukwe, 'when she was pregnant, he beat her until she miscarried'... 'Last year when my sister was recovering from an illness, he beat her again... (P. 67).

Women as represented by Odukwe's sister, Mgbafo, are helpless in a patriarchal world of Achebe as aptly captured using the indicative mood in the excerpt above. The image of helplessness of women is painted very glaringly in the excerpt above. Odukwe as the voice of his sister, Mgbafo recounts the tragic experiences of Mgbafo in the hands of her husband, Ezewulu. Ezewulu constantly beats-up his wife. We are told that 'no single day passed in the sky without his beating the woman'. Women are made to live in fear as they are often battered by their husbands. A man who cannot rule his women is considered a woman. So in order to be a man, beating the women becomes a normal practice. The seriousness of the beatings Mgbafo received from her husband is captured in 'when she was pregnant, he beat her until she miscarried'. Beating is one the measures adopted by men to rule the wives.

It was late afternoon before Nwoye returned. 'Where have you been?' .... 'Answer me, 'roared Okonkwo, 'before I kill you!' he seized a heavy stick that lay on the dwarf wall and hit him two or three savage blows. The women were screaming outside, afraid to go in ... (P. 121).

Okonkwo's temper and disposition towards Nwoye and his household is portrayed in the excerpt above. The expressions such as 'roared Okonkwo', 'before 1 kill you!', seizes a heavy stick', 'hit him two or three savage blows' succinctly portrays the kind of person Okonkwo is. He could be described as a quick-tempered, authoritative and callous individual. His thunderous voice sends shiver down the spine of his victim. He does not merely threaten Nwoye, but practically deals with him in a manner described as savage-merciless manhandling. Fear seized the women who witness this unrestrained vent of anger by a man who is determined to kill. In their helplessness, they resorted to screaming, a characteristic nature assigned to women by society. The only assistance Nwoye could get from the 'wailing women' is their scream.

Okonkwo does not like people who display feminine dispositions. He shows this in the excerpt below:

He, Okonkwo, was called a flaming fire. How could he have begotten a woman for a son? (P. 124).

Okonkwo is restless because of his son, Nwoye. Nwoye has joined the Christian faith contrary to the expectation of his society. Women are believed to be weak in mind and character and this presupposes them to instability and frequent change of decision. Women could embrace the Christian faith but not Nwoye, a man who could take over from his father, a man who will rule over his wives and children. Okonkwo being a real man is metaphorically likened to not just an ordinary fire but a devouring fire, hence, 'called a flaming fire', but 'how 
could he have begotten a woman for a son? This rhetorical expression captures Okonwko's surprise. While men are portrayed to be strong, rigid and determined, women are portrayed to be weak, flimsy and easily tossed about by every new doctrine.

'Lets us not reason like cowards? Said Okonkwo. If a man comes into my hut and defecates on the floor, what do I do? Do I shut my eyes? No! I take a stick and break his head. That is what a man does. These people are daily pouring filth over us, and Okeke says we should pretend not to see... This was a womanly clan, he thought. Such a thing could never happen in my fatherland, Umuofia. (P. 127).

Okonkwo describes Christian activities in Mbanta as 'pouring filth over us' and describes Okeke as a coward because Okeke sues for clam and restraint. 'let us not reason like cowards', Okonwko thunders. He is quick tempered, aggressive, violent and abusive. He calls for war as a blood-thirsty wolf and disdainfully insults Mbanta clan and calls it a 'womanly clan'. To Okonwko, men are to be brave and action-oriented while women are cowards. He declares that such a thing will never happen in his fatherland. It could only happen in his motherland. His fatherland is associated with strength, bravery and courage; while his motherland is associated with cowardice, weakness and timidity.

Although he had prospered in his motherland, Okonwko knew that he would have prospered even more in Umuofia, in the land of his fathers where men were bold and warlike (P. 130).

In the above excerpt, prosperity and success are attributed to the masculine gender. Although Okonwo prospered in his motherland, Mbanta, he knows that greater prosperity lies in his fatherland, Umuofia where men are bold and warlike. The ideology behind this kind of portrayal is the entrenchment of masculinity. No matter how good the woman is, the man is always better and superior. Mbanta is a clan of cowards, without prospects for prosperity. On the contrary, Umuofia is portrayed as a clan of bold and warlike people and success seems to be the attendant of boldness and warlike disposition. Umuofia is a clan of warriors while Mbanta the motherland is a clan of cowards.

In the extract below, the narrator constructs men as people who solely take decisions in their homes. The indicative mood is deployed to aptly capture men as individuals who do not involve their wives in the running of their homes.

The male characters in the novel linguistically construct their sons as men and not women. This kind of portrayal is evident in the extract below:

He sent for the five sons and they came and sat in his Obi. 'You have all seen the great abomination of your brother. Now he is no longer my son or your brother. I will only have a son who is a man, who will hold his head up among my people. If any one of you prefers to be a woman, let him follow Nwoye... (Pp. 137-138).

As far as Okonwko is concerned, embracing the Christian faith is a sign of weakness and feminity. For Nwoye to embrace the Christian faith, he is seen as a woman because to Okonkwo, such triviality as Christianity is stock-in-trade for the women, and not for the men. Men are believed to be stout hearted and can only engage themselves in serious issues. Christianity is not for responsible people, but for the senseless, trivial and timid like people-the women. Okonkwo will only have sons and not daughters. He prefers sons to daughters and any of his sons who join Christianity automatically becomes a woman. He has nothing to do with women because they are not important. Women cannot come out when his Umunna comes out.

Okonkwo was deeply grieved. And it was not just a personal grief. He mourned for the clan ... he mourned for the warlike men of Umuofia, who had so unaccountable become soft like women (P. 146).

Softness is constructed as an attribute of women, not men. A man who is soft is tantamount to a woman. For the clan of Umuofia to become lenient in their treatment of the new religion threatening the long-established way of life and belief system made Okonkwo to mourn for them. They have become unreasonably soft like women. Men who were previously warlike had suddenly become as soft as women. The portrayal shows men as strong-hearted people and women as soft-hearted people.

\section{Conclusion}

Radical feminists argue that language constructs a certain reality and men do the construction while women are excluded in the construction process. To a large extent, this statement is true of Achebe's use of language to create male and female genders, and circumstances and events in Things Fall Apart as revealed in this paper. According to Cameroon (2005), language is a thing which forces 'women's experiences into categories that do not fit' (p. 132). From this perspective, therefore, language does not only help to filter the reality, but also distort the reality. In this study, it has been demonstrated that men and women are cast in different lights, a situation 
made possible by language.

Literature as a socializing engine helps in placing men and women in an unequal grounds where they dance unequal dance. Achebe's linguistic choices reflect the different ways men and women are perceived in the pre-colonial Igbo society. Gender bias and gendered role specifications assigns more privilege, honour and wealth to the masculine gender, while the feminine gender is an appendage to man. In our society, one gender could be seen as superior to the other and this causes some structural inequality in power and economic distribution, a reality discovered in this paper. The study further reveals that chauvinistic and feministic traits of domination, oppression, marginalization and derogation of the female gender are evident in the language and diction of the author, a reflection of the unconscious mind and socio-cultural beliefs about men and women in a patriarchal society.

Language is the symbolic presentation of a culture and Sapir (1956) has maintained that culture is a system of behaviours and modes that depend on unconsciousness. This study has revealed that either consciously or unconsciously, Achebe used language to represent men and women differently. This is the result of the common belief of the people. Women are falsely represented, giving a false impression of their identity and orientation. On the whole, this study has established that culture has a direct effect on language use and language places men and women on uneven positions. Women are therefore presented as common being who can only be seen but not to be heard in Achebe's Things Fall Apart.

\section{References}

Achebe, C. (1991). Things Fall Apart. New York: Fawcett Crest.

Afolabi, O. A., \& Abosede, A. O. (2014). The Depiction of Women in Achebe's Things Fall Apart and Soyinka's The Jero Plays'. Journal of ELT and Applied Linguistics (JELTAL), 2(3), 28-35.

Behringer, M. (2008). Gender in Contemporary Literature. New York: May and Baker.

Butler, J. (1990). Gender Trouble: Feminism and the Identity Subversion. New York: Routledge.

Cameroon, D. (2005). Language, Gender and Sexuality: Current Issues and New Directions. Applied Linguistics, 26(4), 482-502. https://doi.org/10.1093/applin/ami027

Coupland, N., \& Adam, J. (1997). Sociolinguistics: A Reader and Coursebook. New York: Palgrave. https://doi.org/10.1007/978-1-349-25582-5

Duranti, A. (2006). Agency in Language. In A. Duranti (Ed).Companion to Linguistic Anthropology. Maiden MA, Blackwell. https://doi.org/10.1111/b.9781405144308.2005.00006.x

Fairclough, N. (1993). Critical discourse analysis and the commodification of public discourse. Discourse and Society, 4(2), 133-68. https://doi.org/10.1177/0957926593004002002

Fairclough, N. (1995). Media Discourse. London: Edward Arnold.

Fowler, R., \& Hodge, B. (1979). Critical linguistics. In R. Fowler et al. (Eds.), Language and Control (pp. 185-213). London: Routledge and Keegan Paul. https://doi.org/10.4324/9780429436215-10

Guthrie, A. (2011). Language and Identity in Postcolonial African Literature: A Case Study of Chinua Achebe's Things Fall Apart' MA Thesis, U of Liberty.

Moreblessings, Chitauro-Mawema. (2006). Gender Sensitivity in Shonia Language Use.A Lexicographic and Corpus-based Study of Words in Context".Ph.D Thesis.University of Zimbabwe and Oslo.

Ogunyemi, C., Akindutire, I., \& Adelakun, O. (2011). A Study on Gender Consciousness in Nigerian Autobiographical Narratives and Power of the Interview. Journal of Education and Practice, 2(4).

Renzetti, C., \& Curran, D. (1992). Sex- Role Socialization, in Feminist Philosophies. In K. J. Sterba, \& R. Tong (Eds.), New Jersey: Prentice Hall.

Sapir, E. (1956). Selected Writings in Language, Culture and Personality. Berkeley: University of California Press.

Smyth, J., \& Rogers, H. (2003). Male Voices and Perceived Sexual Orientation: An experimental and theoretical approach. Language in Society. https://doi.org/10.1017/S0047404503323024

Zola, W. P. (2010). The Depiction of Female Characters by Male Writers in Selected Isixhosa Drama Works. Ph.D. Thesis. 


\section{Copyrights}

Copyright for this article is retained by the author(s), with first publication rights granted to the journal.

This is an open-access article distributed under the terms and conditions of the Creative Commons Attribution license (http://creativecommons.org/licenses/by/4.0/). 